\title{
【速報】
}

\section{立ち上がり支援機能を有する移動ロボットのための 立ち上がり動作の数理モデル化 Mathematical Modeling of Standing up Motion for a Mobile Robot with Function of Assisting Standing up}

\author{
柴田論 (正会員), 呉志強(非会員), 山本智規 (非会員), 李在勲 (非会員)
}

Satoru Shibata, Wu Zhiqiang, Tomonori Yamamoto, and Lee Jaehoon

\begin{abstract}
Developing robotic systems that can encourage the social activities of the aged or handicapped is important. We propose a mobile robotic system that follows a person, closely monitoring when the person goes out of the house; becomes a chair when the person wants to sit; and assists in the standing-up motion when the person resumes walking. The mobile robot comprises an arc-shaped mechanism to assist in the standing-up motion. In this study, the standing-up motion of a person is analyzed from the viewpoint of the combination of the lateral movement of the knee and the rotational movement of trochanter major when its rotational center is considered to be in the same position as the knee. In addition, the rotational movement of trochanter major and the lateral movement of the knee are modeled using spline functions. The errors between the trajectories obtained by the models and those obtained from experimental data were confirmed to be very small, showing the effectiveness of the models. The mobile robot can reproduce the trajectory of natural standing up by controlling its own movement and the arc-shaped mechanism by following the trajectories of the models.
\end{abstract}

Key Words

Mobile robot, Assist of standing up, Modelling of standing up motion of human, Following human

\section{1. はじめに}

近年, 高齢社会が急速に進展しているが, 高齢化に伴う下肢 機能の低下により外出して歩行することがおっくうになり, それが 生活空間の狭小化につながる危険性がある. そうなると, 生活時 間の多くは家の中で過ごし, 外出や対人接触といった活動の機 会や意欲が減少する状態に陥る.このような閉じこもりによる生活 活動環境の狭小化は, 活動水準の低下を引き起こし, 寝たきりの 原因となるさまざまな問題の引き金になる ${ }^{1)}$.

このような事態に至ることを避けるため, われわれの研究グル ープは, 人間を見守りながら追従し, 休顋の際には椅子の役割を 果たして人間に着座してもらい, 歩行再開のための立ち上がり動

2015 年 11 月 12 日受付

2016 年 1 月 21 日掲載決定

愛媛大学大学院理工学研究科, 干790-8577 愛媛県

松山市文京町 3 番

Graduate School of Science and Engineering, Ehime University, 3, Bunkyo-cho, Matsuyama, Ehime, 790-8577, Japan
作の際には, 筋力不足を補う立ち上がり補助運動を実現して負 担を軽減することが可能な移動ロボットシステムを提案する.これ により, 人間の活動領域を広め, 下肢機能の維持, あるいは回復 にも役立つ可能性があるとともに, 生活行動, 健康状態のモ二タ リングをすることも可能となる.

立ち上がり動作補助に関しては, 空気圧を用いた機器に関す る研究 2,3)や, ロボットの開発 4,5)が種々行われている. 介護支援口 ボットの研究用プラットフォーム”ROBEAR” ${ }^{4}$ (端座位の姿勢をと れる被介護者の前面から抱き上げを行うことができる. 自立支援 型起立歩行アシストロボット ${ }^{5}$ は, 高齢者の起立・着座・静止 (衣 服着脱時)の状態を検知し, 足りない力をモータでアシストするこ とで移動, 移乗, 排泄時などの高齢者の自立的動作を支援する. しかしながら, 人間の歩行を追従しながら見守るという本研究で 提案した機能を有するものは報告されていない. 一方, 人間を追 従する移動ロボットの研究に関しても種々の報告 6-8)がある. 森岡 ら 6)は空間全体に配置されたセンシングデバイスに基づき, 移動 ロボットが人間を追従するシステムを構築している. 奥迫ら 7)はレ 
ーザレンジファインダにより得られる距離データをもとに, 移動ロ ボットによる人間の実時間追従を実現している. 武用ら ${ }^{8)}$ は距離 画像とカラー画像を融合したロボットの人閒追従制御手法を提案 している. しかし, 休憩時に椅子の役割を果たすことや, 立ち上が りを支援する機能を有したものはこれまで報告されておらず, 概 念的に新しいものである.

本報告では，提案した移動ロボットシステムの特徴の一つであ る, 人間の座位姿勢からの立ち上がり補助を実現するための基 礎的アプローチとして, 健常な人間の自然な立ち上がり動作を回 転運動と並進運動の合成としてとらえ, 実験を通じてそれらの特 徵を明らかにするとともにその数理的理解を行う.

\section{2. 提案するサポートロボットのイメージ}

Fig.1 に本報告で提案する移動ロボットのイメージを示す. 移動 ロボットは, 人間が外出する際, 適度な距離を保って人間を見守 りながら追従し, 人間が休憩のために座りたいときは, 座りすい 位置に移動して椅子の役割を果たし, 歩行を再開するときには立 ち上がり動作の支援を行い，また歩行を見守りながら追従すると いらものである.

Fig.2 に提案する移動ロボットを示す. (a)はロボットの構造であ り, 足回りには車輪機構を有している. また, ロボットの上面は人 間にとっての椅子の座面の役割を兼祆ており, この座面が(b)のよ うに回転運動することにより人間の臀部を押し上げ，立ち上がり補 助を行う.

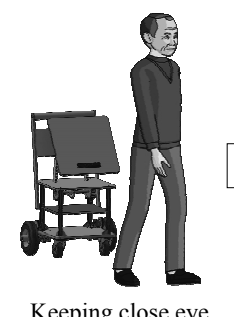
following walking
Keeping close eye

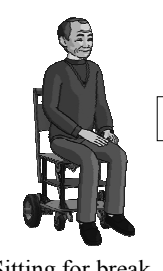

Sitting for break

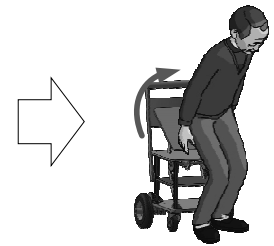

Assisting standing up
Fig.1 Feature of the proposed mobile robot

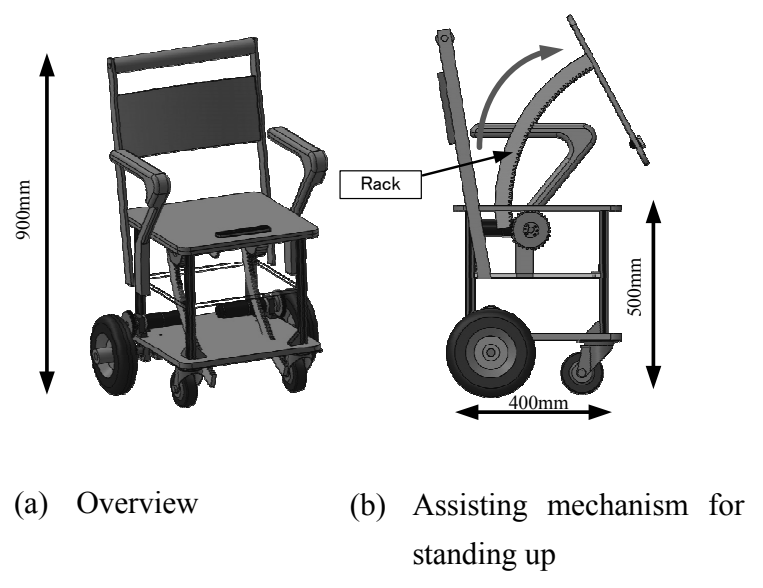

Fig.2 Construction of the mobile robot

\section{3. 立ち上がり動作の計測}

移動ロボットは座面の押し上げ回転運動および本体の並進運 動を同時に行うことにより立ち上がりを補助する.ここでは，人間 の自然な立ち上がり動作における軌道を実験的に解析してそれ らの特徵を回転と並進の合成といら観点からとらえ, 数理的にモ デル化することを試みる.

\section{1 実験方法}

人間の自然な立ち上がり動作を計測するための装置として, PSD センサシステムを用いる. Fig.3 のように, 人間の立ち上がり 動作における膝関節と大転子を椅子から $2500[\mathrm{~mm}]$ 離れた位置 に設置された高さ $650[\mathrm{~mm}]$ と $1150[\mathrm{~mm}]$ の 2 台の PSD カメラによ り計測する. 2 組の PSD センサシステムによる撮影範囲は縦 1300 ×横 $800[\mathrm{~mm}]$ であり, 計測精度は誤差 $1 \mathrm{~mm}$ 未満と非常に高精度 である.

被験者には座位状態からの立ち上がり動作を繰り返し 10 回行 ってもらった. ただし, 立ち上がりを始める際の臀部の位置と足先 の位置はできるだけ同じ位置にするよう指示した.

実験は年齢 22 歳 26 歳, 平均身長 $172 \mathrm{~cm}$, 平均の座高 $92 \mathrm{~cm}$ の 10 名の被験者により行った. ただし, すべての被験者に対して 実験の目的および内容を事前に説明し, 十分なインフォームドコ ンセントが得られた上で実験を実施している.

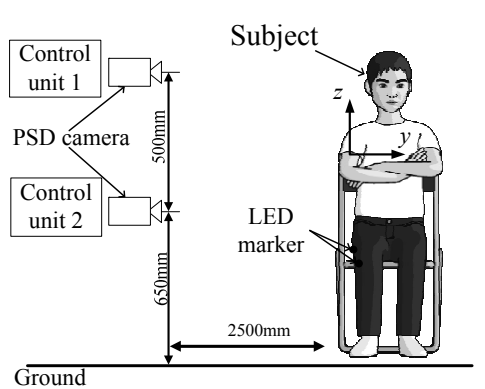

(a) Placement by PSD sensor system

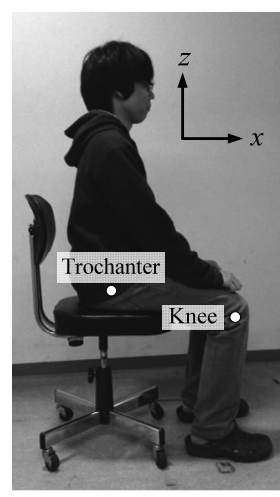

(b) Measured points
Fig. 3 Experimental conditions of standing up measurement

\section{2 実験結果}

実験により得られた膝関節と大転子の軌跡の代表例を Fig.4に示す.ただし, 同じサンプリング時間において膝関節 と大転子を直線で結んでおり， $\theta$ はその直線が水平線とのな す角を表している．膝関節の軌跡はほぼ水平線上において前 後に動いていることがわかる．また，大転子の軌跡は運動の 始点から終点に向かって滑らかな円弧上の曲線を描いている. これらの特徴はすべての被験者に共通するものであった。こ れらの結果から, 膝の並進移動成分を移動ロボットの前後運 動により実現し，大転子の円弧成分を座面回転機構により実 現することが可能であるといえる. 


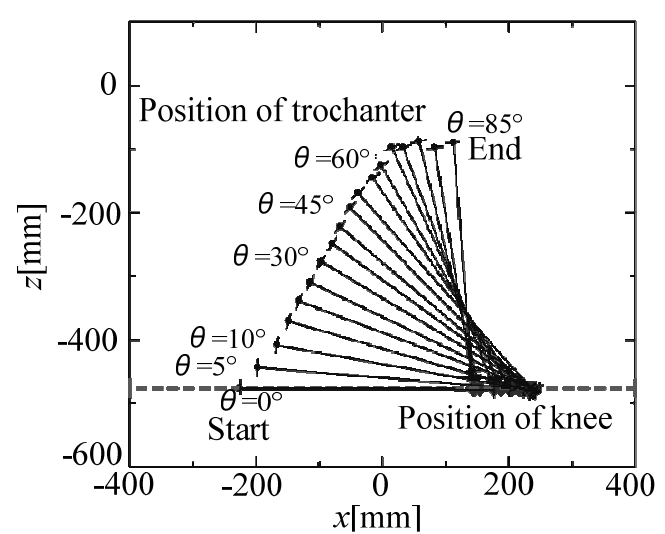

Fig.4 Trajectories of positions of trochanter and knee

\section{4. 立ち上がり動作の解析とモデル化}

計測実験の結果より, 人間の立ち上がり動作は大転子と膝関 節を結ぶ直線の回転運動と膝関節の前後運動の 2 つの合成とと らえることが可能であることがわかった. よって開発する移動ロボ ットシステムにおいて, ロボット本体の足回りによる前後運動と, 座 面制御機構による回転運動にて立ち上がり補助を行うことができ る. 実際にロボットが立ち上がり補助を行う場合, 補助動作に要 する時間や座面の移動速度など様々なパラメータを決定し, それ に従ったロボットの制御を行う必要がある. そこで大転子と膝関節 を結ぶ直線の回転運動と膝関節の前後運動について解析, 正規 化を行いパラメータの決定を目指す.

\section{1 大転子と膝関節を結ぶ直線の回転運動の解析およひ}

\section{数理的理解}

大転子と膝関節の同時刻の計測点を結ぶ直線を仮定し, この 直線と $x$ 軸のなす角を $\theta$ とする. この時, 大転子と膝関節を結ぶ 直線は膝付近を中心とした円弧状の動きとなり, 膝関節を固定し た場合の平均軌道を Fig.5(a)に示す. 図中の黒点はサンプリング ごとの值である.

図のように軌道は 3 つの区間に分けることが出来, 区間 I は下 に凸の滑らかな変化, 区間 II は直線的な変化, 区間IIIは上に凸 の滑らかな変化をしていることが明らかになった.また, 立ち上が りに必要な時間は平均 $0.743 \mathrm{sec}$, 標準偏差 $0.089 \mathrm{sec}$ と個人差が 無視できないものとなった. 回転角度の最終值は平均 $80.9^{\circ}$, 標 準偏差 $5.89^{\circ}$ と個人差が小さいものとなった.

そこでこれらの特徴を示すことが可能な数理モデルによる表現 を試みる. すなわち, 各被験者について立ち上がりに必要な時間 で割って動作時間を 1 と正規化したものの平均軌道について 2 次のスプライン関数を用いた近似(ただし，区間 IIについては 2 次の項の係数值が 0 になっているとみなす)を行う.

具体的には, 時間 $t$ における回転角度を $\theta(t)$ とすると,

$\theta(t)=\left\{\begin{array}{c}a t^{2} \quad\left(0 \leq t \leq t_{1}\right) \\ b t+c \quad\left(t_{1}<t \leq t_{2}\right) \\ d(t-e)^{2}+f \quad\left(t_{2}<t\right)\end{array}\right.$

で表される.

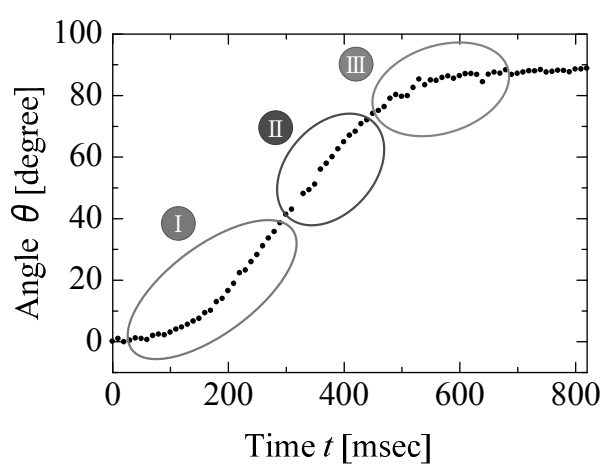

(a) Rotational trajectory of ischium position

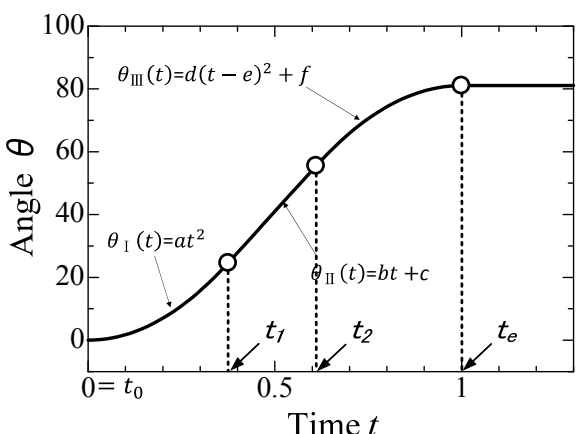

(b) Approximation by mathematical expression

Fig.5 Mathematical understanding of rotational movement of ischium position

これらの近似を行った結果, (1)式の各パラメータは, $a=1.69 \times$ $10^{2}, b=1.27 \times 10^{2}, c=-23.83, d=-1.81 \times 10^{2}, e=1, f=80.9$ といら值 が得られた。

\section{2 膝関節の前後方向運動の解析および数理的理解}

膝関節の水平方向における平均移動軌道を Fig.6(a)に示す. 図を見てわかるように, 最初膝関節は正方向に滑らかに移動する が, ピークを取った後, 滑らかに減少し, 初期点付近まで移動し 静止している.これらを波形の特徵の観点から考察すると, 3 つの 区間 $\mathrm{A}, \mathrm{B}, \mathrm{C}$ 分けることが出来，区間 $\mathrm{A}$ は下に凸の滑らかな変 化, 区間 B は上に凸の滑らかな変化, 区間III は下に凸の滑らか な変化をしていることが明らかになった. また, 膝の前後運動の最 大変位については, 平均 $90.5 \mathrm{~mm}$, 標準偏差 $22.6 \mathrm{~mm}$ と個人差が 無視できないものとなった.

そこでこれらの特徴を示すことが可能な数理モデルによる表現 を試みる. 寸なわち, 各被験者について横軸は大転子と膝関節 を結ぶ直線の回転運動の解析と同じように動作時間を 1 と正規化 し, 縦軸は最大変位で正規化したものの平均軌道について 2 次 のスプライン関数を用いた近似を行う.

具体的には, 時間 $t$ における回転角度を $x(t)$ とすると,

$x(t)=\left\{\begin{array}{cl}g t^{2} \quad\left(0 \leq t \leq t_{a}\right) \\ h t^{2}+i t+j & \left(t_{a}<t \leq t_{b}\right) \\ k(t-l)^{2}+m & \left(t_{b}<t \leq t_{f}\right)\end{array}\right.$

で表される.これらの近似を行った結果，(2)式の各パラメータは， 


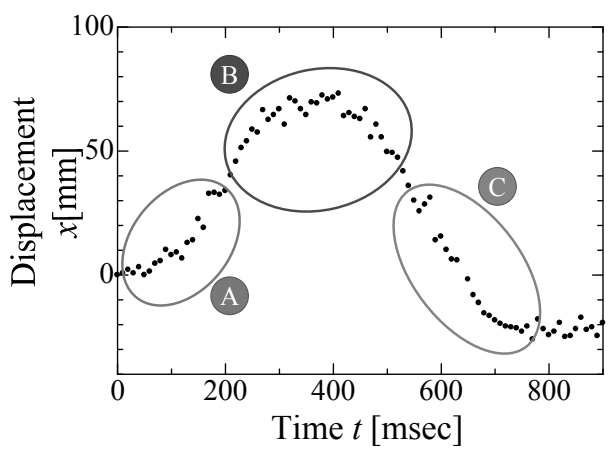

(a) Movement trajectory of knee position

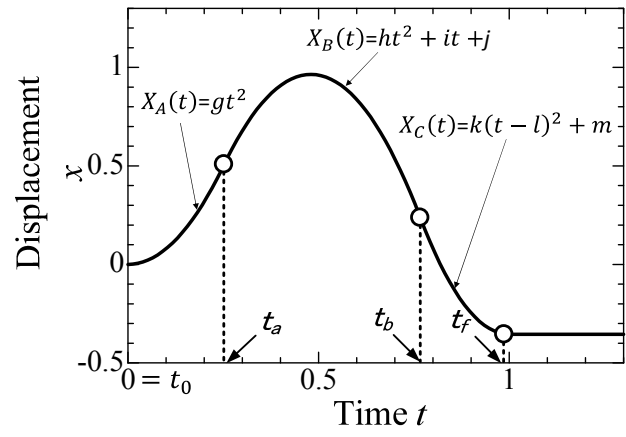

(b) Approximation by mathematical expression

Fig.6 Mathematical understanding of lateral movement of knee position in standing up motion

$g=6.87, h=-11.2, i=10.32, j=-1.48, k=6.09, l=0.928, m=0.053$ と なった.

以上の数理的表現を用いたときの大転子と膝関節の動きは次 式により表すことが出来る. ただし, 大転子の座標には添え字 $w$ を, 膝関節の座標には添え字 $k$ を付している. また, 個人の大転 子と膝関節の距離は $p$ とし, 大転子の初期位置を $(0,0)$ としてい る.

$\left(x_{w}(t), y_{w}(t)\right)=(p(1-\cos \theta(t)+x(t), p \sin \theta(t))$

$\left(x_{k}(t), y_{k}(t)\right)=(p+x(t), 0)$

\section{3 数理的モデルを用いた人間の立ち上がり運動軌道の再現}

得られた数理モデルをロボットの回転機構による回転運動と口 ボット本体の並進運動に適用した際の, 座面に慰部を接触してい る人間の膝関節と大転子の変化を Fig.7 に示す. 図に示されるよ うに, 膝関節の前後運動, および大転子の滑らかな円弧運動が 良好に再現されており, 提案した移動ロボットによる支援動作によ り，人閒の滑らかな立ち上がり動作を実現することが可能であるこ とが示された。

立ち上がり動作の実測值と Fig.7 に示される大転子の 2 乗平均 誤差は, 被験者 11 名で各 5 回の計 55 個のデータについてそれ ぞれ計算したところ, 全体の平均值は $14.1 \mathrm{~mm}$ と小さな值となった. また, そのときの標準偏差は $4.9 \mathrm{~mm}$ となった. このように, 立ち上 がり動作を回転運動と並進運動の合成とみなしてモデル化する

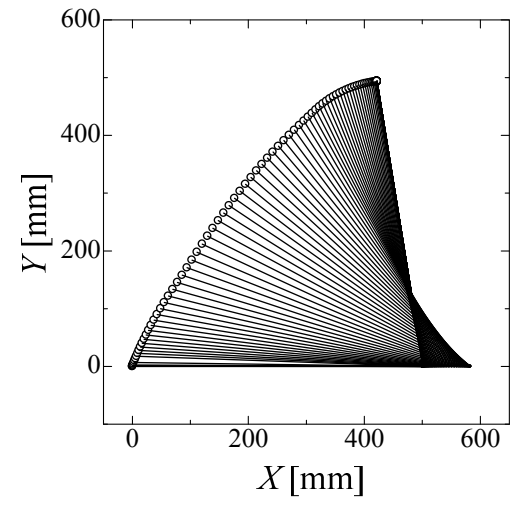

(a) Reproduced trajectory

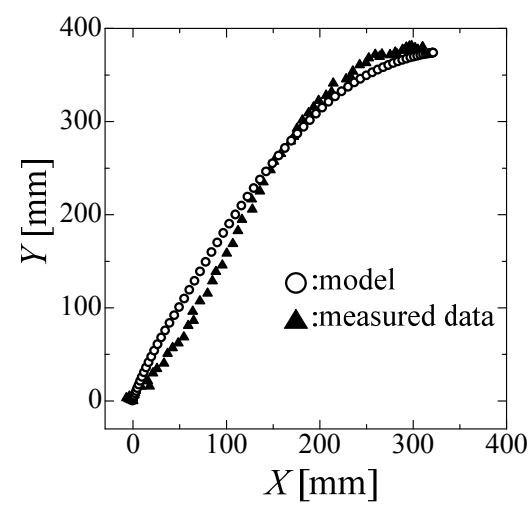

(b) Comparison of model with measured data

Fig.7 Reproduced movement of positions of trochanter and knee by the mathematical model

方法は人間の立ち上がり運動を良好に再現することが可能であ ることが確認できた.

\section{5. まとめ}

本報告では，人間を見守りながら追従し，休憩の際の椅子の 役割, および立ち上がり補助機能を有する移動ロボットシステム を提案し，滑らかな立ち上がり支援動作を実現するための基礎的 アプローチとして, 人間の自然な立ち上がり動作の特徴を実験的 に調べ, その特徴を数学モデルにより表現した. その結果, 人間 の自然な立ち上がり動作は, 膝関節を中心とした大転子の回転 運動と膝関節の水平方向における前後運動の合成ととらえること が可能であることがわかった. また, それぞれの軌道を簡単な数 学モデルで近似表現することが可能であることを示し，それらを口 ボットの座面回転運動とロボット本体の並進運動に適用した場合 に，良好に人間の立ち上がり動作軌道を再現できる可能性を示 した.

立ち上がり支援を行う際に健常者の自然な立ち上がり動作軌 道を規範とすることが望ましいかどうかについては, 坂東ら9やや池 内ら ${ }^{10)}$ の報告からもわかるように必ずしも成り立つとは言えない可 能性がある. 膝関節を中心とした大転子の回転運動と膝関節の 水平方向における前後運動それぞれに望ましい支援軌道が存 
在するのかどうかについては重要であり, 今後明らかにしていき たい.

\section{参考文献}

1）竹内孝仁，老年病とライフスタイル，老年者のライフスタイルと 㸚たきり, GERONTOLOGY-NEW HORIZEN, 東京, メディカ ルレビュー社, 1994; 6: 419-423.

2) 河村隆, 榎本祐嗣, 小林俊一, 水上公博, 空気圧制御によ る立ち上がり補助／下肢トレーニング補助機器の開発. 福祉 工学シンポジウム講演論文集 2006; 191-192.

3) 藤原啓輔, 則次俊郎, 高岩昌弘, 佐々木大輔, 杉野真哉, 空気圧ゴム人工筋を用いた立ち上がり動作支援装置の開発. ロボティクス・メカトロニクス講演会講演概要集 2009; 1P1-K02(1).

4) 理化学研究所, 介護支援ロボットの研究用プラットフォーム ROBEAR. http://rtc.nagoya.riken.jp/ROBEAR/

[2016年 7 月 16 日に確認]

5）パナソニック株式会社，自立支援型起立歩行アシストロボット. http://news.panasonic.com/jp/topics/2014/38643.html [2016年 7 月 16 日に確認]

6) 森岡一幸, 李周浩, 橋本秀紀, 知能化空間における移動口 ボットの人間追従制御。日本ロボット学会誌, 2004; 22(1): 103-111

7）奥迫伸一，坂根茂幸，レーザレンジファインダを用いた移動 ロボットによる人の追跡. 日本ロボット学会誌 2006；24(5): 605-613.

8）武用吉史, 橋本周司, 距離画像とカラー画像のセンサフュー ジョンに基づくロボットの人間追従. 情報処理学会第 70 回全 国大会, 2008; 233-234.

9）坂東直行, 村田明宏, 山田宏尚, 森田啓之, 田中邦彦, 上 肢支援型起立動作補助装置の開発(第 2 報)座面の移動軌道 の関係. 岐阜県生活技術研究報告 2007; 10: 40-43.

10) 池内秀隆, 永利益嗣, 三浦篤義, 床反力を用いた立ち上が り補助装置における補助軌道評価実験. LIFE2014 2014; 11. 